\title{
HABERMAS E A CRÍTICA À EUGENIA LIBERAL
}

Marcos Rohling Doutorando em Educação pela Universidade Federal de Santa Catarina - UFSC

\section{RESUMO}

Pretende-se nesse texto, em primeiro lugar, apresentar os argumentos de Habermas contra a eugenia liberal, mais especificamente, contra a eugenia positiva. Vão-se afirmar, igualmente, os argumentos de Habermas em favor de uma ética da espécie, os quais permitem apenas uma eugenia negativa, isto é, aquela com fins terapêuticos sem que, para isso, seja necessário interferir na estrutura genética, em virtude de, em primeiro lugar, interferir na autocompreensão dos indivíduos como livres e iguais e, em segundo lugar, na irreversibilidade de tais mudanças. Por fim, serão arrolados alguns críticos das teses habermasianas. Esses autores, em geral, apontam para um certo retrocesso da perspectiva do filósofo de Frankfurt por tentar recuperar a ideia de natureza humana.

PALAVRAS-CHAVE: Habermas, Eugenia, Eugenia Liberal, Bioética, Teoria da Justiça.

\section{ABSTRACT}

It is intended that text, firstly introduce Habermas's arguments against liberal eugenics, more specifically, against positive eugenics. Will be said, also, Habermas's arguments in favor of a of species' ethic, which allow only one negative eugenics, $i e$, that for therapeutic purposes without, for that it is necessary to interfere with the genetic structure because of, firstly, interfere with the self individuals as free and equal and, secondly, in the reversibility of such changes. Finally, some critics are enrolled theses habermasians. These authors generally point to a certain setback from the perspective of the Frankfurt philosopher by trying to recover the idea of human nature.

KEYWORDS: Habermas, Eugenic, Liberal Eugenic, Bioethics, Theory of Justice.

\section{Introdução}

Segundo Chitty, o movimento que está associado ao surgimento da eugenia é vinculado ao século XIX e, neste, às figuras de Marx e Darwin. O primeiro por conta da publicação de $O$ Manifesto Comunista, em parceria com Engels, em 1848; e o segundo pela publicação da obra $A$ Origem das Espécies, em 1859. Ambas as obras foram responsáveis pela revisão dos pilares que sustentavam as sociedades de então, marcadas pelo conservadorismo e pela força da tradição e, notadamente, inspiraram, cada qual a seu modo, o ideário intelectual ao qual está adjunto ao florescimento do movimento eugênico (CHITTY, 2009, p. 25-8). 
O termo, todavia, não é relacionado a nenhum deles. Antes, a eugenia é um termo de origem grega, cunhado em 1883, por Francis Galton (1822-1911), que quer dizer, literalmente, bem nascido. Segundo Galton, que tinha um vínculo parentesco com Darwin ${ }^{1}$, a eugenia seria o estudo dos agentes sob o controle social que podem melhorar ou empobrecer as qualidades raciais das futuras gerações seja física ou mentalmente, isto é, o melhoramento da espécie. ${ }^{2}$ Em 1865, Galton publicou um livro intitulado "Hereditary Talent and Genius", no qual procurou defender a ideia de que a inteligência é predominantemente herdada e não fruto da ação ambiental, resultado a que chegou após a observação de 177 biografias, muitas das quais de sua própria família. O propósito de Galton era estabelecer uma ciência cuja finalidade seria a do melhoramento do gênero humano dando às "raças" mais providas uma chance melhor para prevalecer sobre aquelas menos providas (KEVLES, 2003, p. 843). No seu livro, Galton alvitrava que

as forças cegas da seleção natural, como agente propulsor do progresso, devem ser substituídas por uma seleção consciente e os homens devem usar todos os conhecimentos adquiridos pelo estudo e o processo da evolução nos tempos passados, a fim de promover o progresso físico e moral no futuro (GALTON, Hereditary Talent and Genius, citado por GOLDIM, Eugenia, http://www.ufrgs.br/bioetica/eugenia.htm, acessado em 05/06/2010).

Influenciado, assim, pela teoria darwiniana - ou seja, que através da seleção natural as espécies mudam - Galton supôs que a "raça" humana poderia ser igualmente melhorada - isto é, que por meio da eugenia, os seres humanos poderiam se encarregar da sua própria evolução. (KEVLES, 2003, p. 843).

\footnotetext{
${ }^{1}$ Tratava-se de seu primo.

${ }^{2}$ A ideia de eugenia, contudo, nos termos do uso dos meios tecnológicos, à disposição no tempo, para o aprimoramento da "natureza humana", mutatis mutandis, remonta à Platão. É verdade que a questão da eugenia, sendo tratada desde a perspectiva de Platão, é controversa e mereceria um tratamento mais aprofundado num texto específico para as suas implicações. A ideia que a enseja, contudo, em termos simples, é que Platão, se é verdade que não dispunha de instrumentos e aparatos tecnológicos os quais pudessem manipular a natureza biológica do ser humano - o que caracteriza especialmente a eugenia -, é igualmente verdade que, nessa direção, valeu-se do que havia disponível em seu tempo, a saber, a educação, tendo em vista que ela permitiria conhecer as diferenças para serem usadas da melhor forma possível na pólis (VOLPATO DUTRA, 2005, p. 241-2). A sociedade ideal descrita em A República, exempli gratia, consiste, em certo sentido, numa sociedade divida de acordo com a constituição natural dos indivíduos. Tal constituição, consoante aos três tipos de almas, gerava três tipos de classes correspondentes, a saber: a dos guardiões [marcada pelo apetite], a dos produtores [marcada pelo espírito] e a dos governantes filósofos [marcada pela razão] (PLATÂO, 2001, 412b-415b; 457a-d). Assim, Platão traça uma correspondência entre os elementos psíquicos do indivíduo e a classe social à qual pertence. Deste ponto de vista, justo é que cada classe social restrinja-se a realizar as atividades para a qual a natureza mais bem lhe dotou.
} 
Essa temática da eugenia é bastante controversa e geradora de conflitos, hoje ainda mais que antes, muito por conta dos terrores advindos de contextos tais quais aqueles criados pela Alemanha de Hitler, que objetivavam algo como uma eugenia nazista, calcada na ideia de uma pureza racial, em nome do que se propunha a eliminação de grupos étnicos tidos por inferiores, notadamente, os judeus. Ainda que as práticas de técnicas de melhoramento genético estejam sendo usadas atualmente em plantas e animais, existem questionamentos éticos quanto o seu uso em seres humanos, ao que, numa espécie de previsão, muitos cientistas declaram que tal fato pode mudar a natureza humana, dado esse, do ponto de vista filosófico, altamente questionável. ${ }^{3}$

É dentro desse quadro de desconfiança, por um lado, a possibilidade de os seres humanos, como pretendia Galton, tomarem em suas mãos os rumos da evolução e, por outro lado, as imagens obscuras, até então, próprias das obras ficcionais, que abrolham da fabricação de seres humanos - que aparece, em 2001, o escrito de Habermas intitulado O Futuro da Natureza Humana ${ }^{4}$. Esse texto se ocupa de questões resultantes dos avanços da engenharia genética, entre os quais, o da eugenia e o do direito de liberdade de reprodução. A partir da apropriação de um termo cunhado por Nicholas Agar, liberal eugenics, isto é, eugenia liberal, Habermas avalia alguns usos possíveis da engenharia genética nas escolhas reprodutivas humanas, quais sejam: a cura de doenças identificadas no screening genético do embrião e a escolha deliberada de traços desejáveis pelos progenitores (FELDHAUS, 2008, p. 58).

Sendo assim, é objetivado nesse texto, em primeiro lugar, apresentar os argumentos de Habermas contra a eugenia liberal, mais especificamente, contra a eugenia positiva. Vão-se afirmar, igualmente, os argumentos do autor em favor de uma ética da espécie, os quais permitem apenas uma eugenia negativa, isto é, aquela com fins terapêuticos sem que, para isso, seja necessário interferir na estrutura genética. Por fim, serão arrolados alguns críticos das teses habermasianas. Esses autores, em geral, apontam para um certo retrocesso da perspectiva do filósofo de Frankfurt por tentar recuperar a ideia de natureza humana, o que resulta questionável, por certo.

\footnotetext{
${ }^{3}$ Para uma boa introdução a questão que se apresenta, ver: AGAR, N., Liberal Eugenics: In Defense of Human Enhancement, Oxford: Blackwell Publishing, 2004; SANDEL, M. J., The Case Against Perfection. Ethics in the Age of Genetic Engineering. Cambridge, MA: The Belknap Press of Harvard University Press, 2007; DEVOLDER, Katrien. Cloning. In: The Stanford Encyclopedia of Philosophy (Summer 2013 Edition), Edward N. Zalta (ed.), $\mathrm{URL}=$ http://plato.stanford.edu/archives/sum2013/entries/cloning/, acessado em 12/08/13. Para uma visão geral crítica do texto de Habermas, remete-se ao artigo: FELIPE, Sônia T. Equívocos da Crítica Habermasiana à Eugenia Liberal. ethic@, Florianópolis, v.4, n. 3, p.339-359, Dez 2005.

${ }^{4}$ No original, Die Zukunft der menschlichen Natur.
} 


\section{Pontos de Partida da Crítica de Habermas e Eugenia Liberal}

Habermas parte da constatação de que o desenvolvimento de ciências e tecnologias aplicadas à saúde e à vida tornou possíveis intervenções de uma nova forma, as quais podem afetar significativamente a autocompreensão normativa da espécie humana porque minam a fronteira entre aquilo que naturalmente somos (isto é, segundo o acaso da natureza, a loteria natural) e aquilo que escolhemos para nós. No que diz respeito a essa problemática, o frankfurtiano

não adota uma atitude de oposição radical ao desenvolvimento científico enquanto tal, mas sim, uma oposição ao prejuízo que a disponibilidade e uso não regulamentado desta tecnologia poderiam causar a autocompreensão normativa de pessoas que agem de maneira responsável e autônoma (FELDHAUS, 2005, p.310).

Isso quer dizer que o filósofo não é um mero crítico da inovação, mas alguém cuja preocupação centra-se nos efeitos que o uso da biotecnologia possa implicar à autocompreensão normativa da espécie, visto que, com a posse desses novos conhecimentos, estão postos em jogo não apenas questões morais, mas, questões que afetam a espécie humana - e como ela quer se compreender - como um todo, isto é, questões que não apenas influenciam, mas, diretamente afetam o modo como nos constituímos (HONNEFELDER, 2008, p. 74).

Com o propósito de discutir questões desse teor, Habermas parte da distinção entre a teoria kantiana da justiça e a ética do ser si mesmo, de Kierkegaard, e defende a ideia de que o pensamento pós-metafísico deve impor a si próprio uma moderação, quando se trata de tomar posições definitivas em relação a questões substanciais sobre a vida boa ou não-fracassada (HABERMAS, 2004, p. 01). Esse tipo de posição confere um pano de fundo que contrasta com outra questão levantada perante a discussão desencadeada pela técnica genética, a saber: "pode a filosofia se permitir a mesma moderação também em questões relativas à ética da espécie?" (HABERMAS, 2004, p. 01). Ou seja, a filosofia tem direito de adotar uma postura de prudência a propósito de questões envolvendo a ética da espécie ou do gênero humano?

A importância de uma questão como essa está no fato de que os aspectos relacionados à questão não estão sendo realçados nos foros onde essas questões são discutidas, a saber, congressos legislativos, ministérios de saúde e de justiça, o meio empresarial, a comunidade 
científica interessada, entre outros. Ademais, o autor afirma que o "tratamento que se deve dar à pesquisa e à técnica genética circulou em torno da questão do status moral da vida humana prépessoal sem trazer resultados" (HABERMAS, 2004, p. 01-2). Em virtude disso, segundo assinala, adota

[...] a perspectiva de um presente vindouro, a partir do qual um dia possivelmente lançaremos um olhar retrospectivo às práticas, hoje contestadas, considerando-as como precursoras de uma eugenia liberal, regulada pela oferta e pela procura (HABERMAS, 2004, p. 01-2).

Habermas, contudo, mostra-se reticente quanto a algumas práticas, pois a pesquisa com embriões e o diagnóstico genético de pré-implantação - DGPI -

acirram os ânimos sobretudo porque são o exemplo de um perigo que se vincula à metáfora da 'criação de humanos'. Tememos, não sem razão, que surja uma densa corrente de ações entre as gerações, pela qual ninguém poderá ser responsabilizado, já que ela transpassa de forma unilateral e na direção vertical as redes de interação contemporâneas. Em contrapartida a isto, os objetivos terapêuticos, nos quais também todas as intervenções da técnica genética deveriam se pautar, impõem limites estreitos a toda interferência. Um terapeuta tem que considerar a segunda pessoa e precisa poder contar com seu consentimento (HABERMAS, 2004, p. 02. Ver também p. 99).

Segundo evidencia Volpato Dutra, Habermas parte do pressuposto de que o entendimento da ética como estudo da vida correta, significando isto o sentido exemplar de um modelo de vida a ser imitado, tornou-se um empreendimento teórico muito difícil para a filosofia, haja vista o fato do pluralismo cultural e das cosmovisões diferentes. Neste sentido, afirma que, para Habermas, as teorias da justiça situam-se num metaplano, sem tomar posição com relação a conteúdos. Assim, entende que as teorias da justiça não podem estabelecer uma forma particular de vida que possa ser imposta às demais. Segundo Volpato Dutra, in verbis:

O máximo que ela pode estabelecer são regras negativas no sentido daquilo que não pode ser desrespeitado por nenhum sistema de convivência justo, como, por exemplo, a tolerância em questões religiosas, a qual pode ser operacionalizada seja no sentido da separação entre religião e Estado, como no modelo franco-americano, de forma que as igrejas possam usar a bandeira do Estado, mas não vice-versa, seja no sentido da imparcialidade, como no modelo belga e em alguns países do norte da Europa. Assim, a questão ética concerne fundamentalmente à identidade: quem somos? O que queremos ser? (VOLPATO DUTRA, 2005, p. 245).

Depreende-se disso o limite das teorias da justiça frente às concepções particulares de vida: não é possível que estabeleçam normas éticas que galguem a aceitação de todos (e, que não 
sejam impostas) se se quiser respeitar a liberdade, sobretudo, a liberdade moderna de autodeterminação. A implicação disso é que a eugenia encontra-se numa situação limítrofe, isto é, se se pensar, numa direção num caso como aquele do aborto, como Dworkin o entende ${ }^{5}$, verbi gratia, ver-se-á que tanto a eugenia quanto o aborto ainda não dispõem de critérios neutros, imparciais para que se estabeleçam normas de orientação, em relação à regulamentação da prática. Por isso mesmo, em vista da ética da espécie, o ser humano deve impor limites à prática eugênica, porque "quando nos faltam razões morais que nos forcem a uma determinada atitude, temos de nos ater aos indicadores éticos da espécie" (HABERMAS, 2004, p. 98).

Assim, como indica Honnefelder, o empreendimento de Habermas difere daquele que um autor como Dworkin leva a efeito, pois, embora o herdeiro da escola de Frankfurt partilhe do diagnóstico estabelecido por esse filósofo, qual seja, a do fracasso da modernidade ante a definição da felicidade (HABERMAS, 2004, p. 44; DWORKIN, 2009) e, por consequência, do que é o bem a partir das concepções metafísicas, as consequiências extraídas, em termos de um posicionamento, são diametralmente opostas (HONNEFELDER, 2008, p. 74-6). Nesse contexto, Habermas advoga que, em função de as questões que envolvem a engenharia genética alterarem a fronteira entre aquilo que é dado e aquilo que é resultado das escolhas, e mudarem a autocompreensão moderna dos indivíduos como seres livres e iguais, essas questões devem ser resolvidas tendo em vista uma ética da espécie (HABERMAS, 2004, p. 39-40), ao passo que o filósofo estadunidense argumenta em prol de uma eugenia liberal tendo em vista ser enganoso cogitar que a mudança entre o acaso/escolha, isto é, entre natural/contingência, possa mudar a própria moral. Assim, devem-se aceitar as mudanças, não impedi-las (DWORKIN, 2002, p. 446$50)$.

Externando certa reticência em relação a uma concepção de programa eugênico, como a de Agar, em Liberal Eugenics (HABERMAS, 2004, p. 68, n. 40), Habermas posiciona-se

\footnotetext{
${ }^{5} \mathrm{O}$ caso que se tem aqui em tela e que estabelece paralelos com a eugenia é aquele do aborto, embora seja verdade que são casos diferentes e que tratam de aspectos morais diferentes: o primeiro tem em vista proteger o patrimônio genético ao mesmo em que considera o direito dos pais de ponderar suas preferências; e o segundo trata do conflito entre o direito de procriação e autoderminação da mãe e o direito à vida do feto. Conforme Dworkin diagnostica, no que se refere a essa questão, não existem padrões aceitáveis, do ponto de vista moral, que sejam imparciais, porque não existe um critério neutro que descreva atributos ontológicos os quais possam determinar o feto ou o embrião como pessoa. Da inexistência desse critério, por sua vez, Dworkin extrai posicionamentos que justificam o aborto, deslocando o argumento para a liberdade religiosa. A ideia do autor, então, é a de que, como o aborto toca na questão do valor intrínseco da vida, de forte matiz religioso, deve ser deixada à liberdade religiosa, de tal modo que, segundo argumenta, a Suprema Corte America, em 1973, agiu corretamente ao permitir o aborto. Cf. DWORKIN, 2000, p. 427-52; 2009, p. 230-46. Ver também: VOLPATO DUTRA, 2005, p. 248-9;
} 
contrário à eugenia de tipo liberal. Enquanto pode-se ver a eugenia como a intervenção tecnológica na natureza biológica do ser humano, a eugenia liberal seria a disposição dessas intervenções (não reconhecendo limites entre as de tipo terapêutico daquelas de aperfeiçoamento) à livre vontade dos progenitores, tal e qual é regulada pelas leis do mercado, contexto esse em que o Estado é neutro, não intervindo de forma alguma (HABERMAS, 2004, p. 26-7; 62). Nesse contexto, tais intervenções (de eugenia positiva, porque teriam em vista a melhoria da raça) não teriam em vista fins terapêuticos, como seria o caso da eugenia negativa, que tem por fito evitar doenças. Ou seja,

Nas sociedades liberais, seriam os mercados que, regidos por interesses lucrativos e pelas preferências da demanda, deixariam as decisões eugências às escolhas individuais dos pais e, de modo geral, aos desejos anárquicos de fregueses e clientes (HABERMAS, 2004, p. 68).

Assim, considerando a radicalização da liberdade, inclusive para intervir na escolha de características humanas, Habermas afirma que o programa da eugenia liberal, qual seja, aquele do acesso à informação sobre toda a série de terapias genéticas as quais permitiriam aos futuros pais que observem seus próprios valores ao selecionarem melhorias para seus filhos, sem a intervenção do Estado, "só é compatível com o liberalismo político, se as intervenções eugênicas positivas em pessoas tratadas geneticamente não limitarem nem as possibilidades de uma conduta de vida autônoma, nem as condições de um trato igualitário com outras pessoas" (HABERMAS, 2004, p. 68), inclusive os progenitores.

\section{A Ética da Espécie e os Limites da Eugenia Liberal}

Com o objetivo de distinguir casos possíveis de casos em que tal prática não poderia ser permitida, como acenado, Habermas recorre, então, ao que chama de ética da espécie, pois considera que não existem critérios normativos na moral convencional capazes de avaliar adequadamente os casos difíceis suscitados pela biotecnologia moderna aplicada à Medicina reprodutiva, com vistas à manipulação do material genético (FELDHAUS, 2008, p. 58).

No curso dos seus argumentos, o filósofo alemão recorre à tradicional distinção entre eugenia negativa e eugenia positiva para estabelecer o critério que permite distinguir entre os casos em que se pode realizar a eugenia daqueles em que não se pode. Aqui se deve pontuar que o sentido que Habermas dá aos termos eugenia negativa e eugenia positiva (HABERMAS, 2004, 
p. 26-7) é diverso daqueles que os eugenistas davam, no final do século XIX e início do século $\mathrm{XX}$, que num plano maior, conduziu aos conhecidos projetos preconceituosos nazistas, culminando no extermínio em massa nos campos de concentração. Cabe distinguir, portanto, a eugenia negativa, usada para evitar doenças com intervenção terapêutica de eugenia positiva, cuja finalidade, segundo entende Habermas, é o de melhorar a raça, isto é, a intervenção para melhorar características da espécie. A questão normativa da eugenia liberal, para o filósofo, coloca-se no sentido de uma extrapolação que afeta a liberdade ética do ser humano geneticamente manipulado, diferentemente deste projeto de seleção artificial dos mais aptos e capazes de reproduzirem-se na esperança de acelerar a evolução dos traços desejáveis, assim como a eliminação dos indesejáveis.

O que é incômodo nesse tipo de questão é que a biotecnologia permite que se possa mexer na linha divisória entre a natureza que nós somos e aquilo que podemos só cultivar, mas não alterar. É a linha divisória entre ser corpo, que é determinante causalmente, e ter corpo, o que não se opera pela causalidade. Ademais, Habermas não tem em mente, em suas análises, uma eugenia perversa, mas aquela boa intenção, normalmente promovida por pais bem intencionados a respeito do futuro de seus filhos (VOLPATO DUTRA, 2005, p. 245).

O problema habermasiano é saber se com a transposição da atual fronteira entre dado pela natureza e disponível ao homem está afetando a autocompreensão moral de uma forma significativamente diferente daquela que até agora ocorreu. Na confirmação deste prognóstico, apresentar-se-ão duas possibilidades divergentes, a saber: se deve-se regular normativamente tal ação ou se a deve deixar, nos termos rawlsianos, às concepções de bem. No tocante a isso, Habermas acredita que se possa divisar que a biotecnologia, senão hodiernamente, mas, pelo menos no futuro, possa atentar contra a autocompreensão normativa decorrente da modernidade, que nos define como espécie (HABERMAS, 2004, p. 40-1).

Nesse sentido, Habermas acredita que a eugenia liberal, principalmente a eugenia positiva, causa graves danos a nossa autocompreensão normativa moderna, isto é, a nossa moral convencional, principalmente por conta de a responsabilidade, a imputabilidade e a simetria, nas relações entre os membros da comunidade, serem afetadas. O ponto reside em que até o momento as condições biológicas da autobiografia não estavam disponíveis num sentido qualitativamente significativo. Essa indisponibilidade da base biológica é, para Habermas, um pressuposto necessário da autodeterminação e das relações igualitárias (HABERMAS, 2004, p. 18-21). 
Segundo Habermas, com a decisão irreversível em vista de um melhoramento genético, que uma pessoa toma em relação à constituição que é dada pela natureza, surge uma nova relação interpessoal, que, até o momento, ainda não existia, e que fere, por assim dizer, a sensibilidade moral das pessoas, porquanto formar um corpo estranho nas relações de reconhecimento legalmente institucionalizadas nas sociedades modernas. O problema dessa nova relação reside justamente no fato de que, quando um indivíduo toma, no lugar de outro, uma decisão irreversível, existe uma interferência profunda na constituição orgânica daquele que sofre as conseqüências dessa decisão, de tal modo que a simetria da responsabilidade, que marca a relação entre pessoas livres e iguais, torna-se limitada (HABERMAS, 2004, p. 20). Dessa feita, Habermas afirma, in verbis:

Perante nosso destino determinado pela socialização, preservamos fundamentalmente uma liberdade diferente da que teríamos com a produção prénatal do nosso genoma. $\mathrm{O}$ jovem em crescimento poderá um dia ele mesmo assumir a responsabilidade por sua história de vida e por aquilo que ele é. Com efeito, ele pode se colocar de modo reflexivo perante seu processo de formação, elaborar uma autocompreensão revisória e compensar, de maneira aprofundada e retrospectiva, a responsabilidade assimétrica dos pais em relação à educação dos filhos. Essa possibilidade de uma apropriação autocrítica da história da própria formação não ocorre do mesmo modo em relação às pessoas que sofreram manipulação genética. Ao contrário, o adulto nesse caso permaneceria totalmente dependente da decisão tomada por um terceiro e que não pode ser reconsiderada, e não teria a chance de estabelecer a simetria da responsabilidade, necessária para o relacionamento entre peers (iguais), seguindo o caminho retroativo de uma auto-reflexão ética. Ao descontente restaria apenas escolher entre o fatalismo e o ressentimento (HABERMAS, 2004, p. 20-1).

Segundo o filósofo, a eugenia positiva cria uma relação assimétrica entre a prole e seus progenitores. Além disso, acredita ainda que, no que pertine à responsabilidade, os indivíduos resultantes de intervenções eugênicas positivas seriam incapazes de se compreenderem como autores indivisos de seu plano racional de vida. Assim, essa intromissão na determinação do plano racional de vida de outra pessoa consistiria num tipo de violação da liberdade ética ou a de escolher a maneira de buscar a própria felicidade, elemento este que é garantido, atualmente, pelas constituições liberais e democráticas.

Habermas entende que o uso da engenharia genética, no sentido de uma intervenção heterônoma, isto é, aquela que não se restringe tão somente à cura de doenças, nos termos de uma eugenia negativa, e insere-se no da eugenia positiva [aperfeiçoamento genético do ser humano], é 
injustificado desde a perspectiva de uma ética da espécie porque afeta os pressupostos normativos da autocompreensão moderna dos seres humanos como livres e iguais. Nessa linha, a engenharia genética afeta os limites entre liberdade e natureza, pois que amplia o espaço de intervenção humana nos elementos que ocupam papel relevante na formação da identidade da espécie humana conjunta e individualmente. Por meio da engenharia genética, os limites daquilo que são naturalmente dados são transpostos, de modo a poder-se alterar o modo como os indivíduos venham a se compreender, numa relação entre iguais.

Volpato Dutra argumenta que, até esse ponto, a argumentação habermasiana pode ser resumida nos seguintes passos:

1) a natureza biológica determina ou condiciona a liberdade;

2) até o tempo presente os elementos naturais foram indisponíveis;

3) a biotecnologia está tornando disponível a interferência em tais elementos;

4) essa interferência influencia a busca da felicidade por cada um e altera as relações sociais;

5) dados os desentendimentos na matéria, as propostas caem sob o domínio da ética [...] fazendo com que a doutrina da vida correta se renove num sentido antropológico (VOLPATO DUTRA, 2005, p. 246-7).

Além disso, se entende-se que a discussão seja centrada no domínio das concepções de bem e não do domínio da justiça, abre-se a possibilidade de uma eugenia liberal. ${ }^{6}$ Todavia, dada a importância da temática, cabe realmente questionar, dentro da perspectiva habermasiana, se deve-se deixar essa eugenia liberal às preferências individuais, ou se os fundamentos naturais e normativos da vida humana merecem outro tratamento. Isto é,

\begin{abstract}
trata-se de saber o quanto esse fato interfere na visão de nós mesmos, naquilo que nos define como espécie, ou seja, na presunção de que somos autores de nossa própria vida e nos reconhecemos uns aos outros como pessoas iguais. Nesse sentido, a discussão da biotecnologia não é um novo enfeitiçamento da modernidade, mas uma reflexão da modernidade em seus limites [...]. Trata-se de resistir a secularização num domínio onde ainda não estão disponíveis argumentos normativos seculares, ou seja, a partir da própria discursividade, ainda incapaz de oferecer fundamentos normativos próprios a conteúdos antes adstritos às formas de vida religiosas (VOLPATO DUTRA, 2005, p. 247).
\end{abstract}

No fundo, a questão é saber se a proteção jurídica da integridade de uma hereditariedade não manipulada pode ser justificada pela referência à noção de nossa própria identidade, que

\footnotetext{
${ }^{6}$ É oportuno enfatizar que, na visão de Habermas, a eugenia liberal é aquela que: i) é regulada pela oferta e demanda e ii) fica além dos fins estritamente terapêuticos, como é o caso da eugenia negativa. Cf. HABERMAS, 2004, p. 26$7 ; 62 ; 67-8$.
} 
contem a ideia de que os fundamentos biológicos sejam algo indisponível. Nessa perspectiva, isso ganharia forma no direito a uma herança genética isenta de manipulação não se permitindo que se disponha da base biológica do que nós somos por natureza (VOLPATO DUTRA, 2005, p. 248).

Quando se olha a vida humana pré-pessoa (aquela que antecede o nascimento), toca-se na questão da própria identidade enquanto seres humanos, no auto-entendimento como membros da espécie humana. É assim, a visão sobre o homem como sendo o mesmo em todas as culturas. Desse modo, para Habermas, há a necessidade de uma antropologia que seja adequada à moral, pois o filósofo entende haver uma conexão entre autocompreensão moral e considerações éticas concernentes aos homens como espécie. Isto é, a autocompreensão dos homens como livres e iguais depende, em alguma medida, da compreensão antropológica como membros da espécie (HABERMAS, 2004, p. 55-6). É essa a ideia que Habermas entende por moralização da natureza humana, pois a dignidade humana está diretamente relacionada com o modo a partir do qual o homem concebe-se como membro da espécie humana. Tal fato, como exemplo, “determina se um embrião tem ou não direitos constitucionais assegurados, como pessoa, pois é preciso saber se ele já é membro da espécie e como é membro da espécie" (VOLPATO DUTRA, 2005, p. 247).

Para Habermas, mexer na natureza humana altera o auto-entendimento do homem como eticamente livre e moralmente guiado por normas. Isso porque a engenharia genética ao possibilitar experiências não existentes ulteriormente, toca na noção de auto-realização e autodeterminação. Assim, isso muda a linha entre o subjetivo e o objetivo, entre o natural e o artificial, pondo à disposição do homem aquilo que antes não estava na sua esfera de ação. "Isso pode alterar o modo como o homem se concebe como autor de sua vida, bem como a noção fundamental de igualdade entre todos, podendo gerar relações assimétricas entre as pessoas" (VOLPATO DUTRA, 2005, p. 260). Além disso, segundo Habermas,

[...] uma eugenia liberal afetaria não apenas o ilimitado poder ser si mesmo, pertencente à pessoa programada. Tal prática produziria, ao mesmo tempo, uma relação interpessoal, para a qual não há nenhum caso de precedência. Com a decisão irreversível, que uma pessoa toma sobre a composição desejada do genoma de outra, surge entre ambas um tipo de relação, que questiona um pré-requisito até então evidente da autocompreensão moral de pessoas que agem e julgam de maneira autônoma. Uma compreensão universalista da moral e do direito parte da ideia de que nenhum impedimento de princípio se opõe a uma ordem igualitária de relações interpessoais. [...] a convicção de que todas as pessoas recebem o mesmo status normativo e devem umas às outras um reconhecimento recíproco e simétrico parte de uma reversibilidade fundamental das relações inter-humanas. Ninguém 
pode depender do outro de modo fundamentalmente irreversível. Com a programação genética, surge, no entanto, uma relação assimétrica em muitos aspectos - um paternalismo sui generis (HABERMAS, 2004, p. 88).

Volpato Dutra afirma que é nesse contexto que Habermas avalia o que chama de intuição relacionada à indisponibilidade da vida humana, de tal forma que não possa ser considerada como um bem entre outros. Isso, num sentido, por conta da importância da matéria em questão para a autocompreensão moral da modernidade. Noutro sentido, poder-se-ia arguir que as práticas eugênicas não são compatíveis com o liberalismo, pois limitam a capacidade de a pessoa levar uma vida autônoma e tocam nas relações de simetria e igualdade entre as pessoas (VOLPATO DUTRA, 2005, p. 261-3). Seria uma forma de proteção do liberalismo contra si mesmo. A liberdade eugênica dos pais não deve tocar a liberdade ética dos filhos, não se deve intrometer na vida ética, pois a liberdade de escolher a própria vida é um dos fundamentos básicos do liberalismo. Além disso, Habermas argumenta que intervenções eugênicas visando à otimização, reduzem a liberdade ética, principalmente se as intenções eugênicas programadas por terceiras pessoas forem irreversíveis (HABERMAS, 2004, p. 69-74).

Ademais, o filósofo entende que o termo eugenia liberal é portador de uma contradição, que vai contra seus próprios pressupostos. Isso porque os liberais defendem a eugenia positiva com base no direito à liberdade reprodutiva. A liberdade à qual atenta Habermas, todavia, e essa é a pedra de toque, não é a liberdade reprodutiva dos progenitores, mas sim a liberdade ética do indivíduo em que o embrião irá se tornar. Nesse sentido, os progenitores, ao selecionarem alguns traços desejados, sem o consentimento do interessado, estariam limitando o espaço dentro do qual aquele indivíduo poderia exercer o direito tão apregoado pelos liberais de empreender livremente seu plano racional de vida (HONNEFELDER, 2008, p. 75-6).

Para discriminar os casos de intervenção genética permitidos, mas não prescritos, dos proibidos, Habermas usa como critério de teor normativo da possibilidade de se presumir o consentimento, ou não, do indivíduo em que o embrião irá se tornar. Além disso, Habermas considera ser possível supor que um indivíduo consentiria com uma intervenção que eliminasse o risco, mediante a eliminação do gene (ou genes) correspondente à presença de doença com base genética. Nesse caso, ter-se-ia a intervenção genética com fins terapêuticos.

Contudo, o filósofo, igualmente, considera impossível - ou problemático, pelo menos supor que um indivíduo consentiria com uma intervenção que selecionasse traços que o 
predeterminassem a algum plano racional de vida ou conjunto de habilidades. Isso decorre da ideia que Habermas tem de que possuir dotes genéticos que uma determinada habilidade limita as possibilidades de empreender outros projetos racionais de vida. O ponto nevrálgico de Habermas, quanto a isso, é a pretensão dos progenitores de concretizar as intenções que os levaram a empreender a manipulação genética, pois uma vez que se realize a intervenção genética, os pais farão de tudo para que se manifeste no fenótipo do filho aquilo que foi geneticamente modificado. (HABERMAS, 2004, p. 87-90). Assim, conclusivamente, no que se refere à eugenia positiva, o autor afirma que

Práticas de eugenia de aperfeiçoamento não podem ser "normalizadas" de modo legítimo no âmbito de uma sociedade pluralista e democraticamente constituída, que concede a todo cidadão igual direito a uma conduta de vida autônoma, porque a seleção das disposições desejadas a priori não pode ser desatrelada do prejulgamento de determinados projetos de vida (HABERMAS, 2004, p. 91-2).

No que se refere à eugenia negativa, por sua vez, Habermas reconhece que não é tão problemática quanto à eugenia positiva. Tal posição assenta-se no fato de que, por um lado, ela não atenta contra os pressupostos normativos daquilo que denominou de ética da espécie, e, por outro lado, permite presumir o consentimento da pessoa futura em que o embrião geneticamente modificado tornar-se-ia. Todavia, Habermas argumenta que ela pode ser apenas permitida, mas não prescrita. Neste particular, o autor aponta que, a partir dos discursos reais, cada sociedade deve decidir, democraticamente, quais tipos de intervenções podem ser consideradas permitidas ou não permitidas. Habermas quer dizer com isso que não cabe ao filósofo decidir aprioristicamente os casos de intervenções eugênicas negativas autorizadas por lei.

\section{Críticas à Concepção de Habermas}

Serão apresentadas algumas críticas emergidas contra as ideias desenvolvidas por Habermas, em O Futuro da Natureza Humana. ${ }^{7}$ Esta apresentação é meramente propedêutica, não visando, portanto, o desenvolvimento das ideias elaboradas pelos críticos de Habermas, no tocando à bioética, com especial atenção à eugenia. Entre os principais críticos destacam-se,

\footnotetext{
7 Tais apresentações são meramente introdutórias e fundadas não somente, mas em grande medida, no artigo "Habermas, ética da espécie e seus críticos", de FELDHAUS.
} 
principalmente, Fenton, Mameli, Lafont, Kersting e Malmqvist, além de Dworkin e Nagel (FELDHAUS, 2007). Desses, contudo, por uma questão de economia textual e de tratarem especificamente da natureza humana e da responsabilidade, serão apontadas as de Fenton e de Mameli.

Para Elizabeth Fenton, Habermas comporta-se, ao lado de Fukuyama e Annas, como um defensor da ressacralização da natureza humana. A natureza humana seria, então, nessa perspectiva comum, algo sagrado em relação a qual a eugenia liberal comportar-se-ia como uma ameaça. ${ }^{8}$ Esta ideia é desenvolvida em Liberal Eugenics \& Human Nature: Againt Habermas . Segundo Feldhaus, Fenton assevera que Habermas defende quatro teses as quais são por ela rejeitadas, a saber:

1) a eugenia liberal ameaça a dignidade humana e os fundamentos da comunidade moral como conseqüência disso;

2) ela altera as relações na comunidade moral;

3) ela mina a igualdade moral; e, finalmente,

4) ela mina a liberdade individual e a autonomia (FELDHAUS, 2007, p. 106-7).

Segundo a autora, a estratégia de argumentação habermasiana, em O Futuro da Natureza Humana, mostra-se como atraente em razão da sofisticação e do número de detalhes, entretanto, ainda vinculada à forma básica da human nature objection. Neste particular, segundo Feldhaus, a autora afirma que "Habermas tenta estabelecer que a natureza humana seja intrinsecamente valiosa, mas isso claramente é equivocado como uma interpretação do argumento de Habermas, pois em momento algum Habermas enuncia ou ressalta a intenção de mostrar tal tese" (FELDHAUS, 2007, p. 108). Contudo, e isso é relevante, Habermas parece não negar, em $O$ Futuro da Natureza Humana, essa tese (HABERMAS, 2004, p. 46-7).

Feldhaus sustenta que Fenton faz uma leitura de Habermas como tentando derivar conclusões normativas de fatos. Nesse sentido,

\footnotetext{
${ }^{8}$ De acordo com o que salienta Feldhaus, “[...] a natureza humana se torna importante, para Habermas, segundo ela, porque envolve a autonomia e a liberdade de desenvolver a própria história de vida. Por proteger a natureza humana, o frankfurtiano então entende proteger uma forma de auto-compreensão normativa e este nexo entre natureza humana e auto-compreensão normativa é resultado da 'modernidade ter-se tornado reflexiva'. Nas próprias palavras de Habermas, moralizar a natureza humana é proteger "as condições sob as quais a autocompreensão normativa da modernidade pode ser preservada.” Cf. FELDHAUS, 2007, p. 106-7.
} 
ela tenta identificá-lo como um defensor da sacralização da natureza humana e juntamente com isso ressalta reiteradamente que a natureza humana não tem status normativo, entretanto, Habermas claramente opõe-se a qualquer tipo de estratégia argumentativa que busca derivar valores de fatos, inclusive quando aborda temas de bioética como a clonagem (FELDHAUS, 2007, p. 108).

Além disso, entende que outra ideia problemática, no que tange a interpretação de Habermas, é consistente na atribuição de uma tendência de Habermas a considerar a natureza humana como algo fixado, pois tal entendimento seria contraditório com a estratégia argumentativa de Habermas uma vez que a natureza humana poderia ser alterada pela eugenia liberal, redundando num desrespeito à liberdade, pois tocaria direta e decisivamente no modo como se dá a autocompreensão normativa moderna de moralidade (FELDHAUS, 2007, p. 108-9).

Em Reproductive cloning, genetic enginnering and the autonomy of the child: the moral agent and the open future, de 2007, Mameli reconhece que a versão de Habermas é uma influente versão da objeção que se refere à autonomia dos descendentes quanto ao uso da clonagem e experimentos genéticos para os propostos de reprodução humana (MAMELI, 2007). Nesse sentido, desenvolve outra linha de objeção às teses desenvolvidas por Habermas, no sentido de que a eugenia liberal e a clonagem reprodutiva não afetam a autonomia da pessoa geneticamente manipulada. O que ele tem em conta é que a responsabilidade pelas ações da pessoa geneticamente manipulada não é minada pela nova tecnologia, pois se o genoma tem um papel importante no desenvolvimento da constituição psicológica básica, ninguém, contrariamente, é plenamente responsável por sua constituição psicológica (FELDHAUS, 2007, p. 114). Ora, a ideia básica aqui é a de que a responsabilidade escapa às determinações oriundas da tecnologia. Um argumento similar tem Dall'Agnol quando afirma que, qualquer que seja a técnica de reprodução biotecnológica, ela não afeta necessariamente, ou por princípio, a pessoalidade do novo ser e, principalmente, não determina seu plano de vida, posto que cada pessoa, além de suas características genéticas, é fruto de um processo criador, educativo, ampliador de potencialidades inatas, socializador e atribuidor de direitos e deveres (DALL'AGNOL, 2005, p. 321-2).

De acordo com o entendimento de Feldhaus, a crítica de Mameli à Habermas baseia-se num raciocínio condicional, qual seja, o de que se responsabilidade plena pelas ações exige que se seja completamente responsável pela constituição psicológica, então, ninguém poderia ser plenamente responsável por suas ações. Dessa sorte, não seria possível a utilização do critério que, segundo o juízo de Mameli, Habermas usa no sentido de diminuir a responsabilidade das 
pessoas geneticamente tanto manipuladas, quanto clonadas. Essa, no entanto, não é posição de Habermas, e Mameli reconhece isso. Como Feldhaus deixa claro, para Mameli a visão de Habermas seria algo próximo a um posicionamento do tipo em que alguém pode ser plenamente responsável por suas ações apenas se sua constituição psicológica não é o resultado desejado de outras pessoas (FELDHAUS, 2007, p. 114). Isso quer que

[...] a contingência de nossa herança genética é conditio sine qua non da responsabilidade, todavia, esta posição teria o problema que grande parte dos aspectos psicológicos de quase todos os seres humanos é o resultado desejado de escolhas dos pais relativas ao meio. Para Mameli, um fato não pode implicar nenhuma conseqüência normativa. Ou seja, o fato de uma g-people ter constituição psicológica parcialmente desejada pelos pais, não implica que é menos responsável do que as pessoas padrões. A única diferença é que são escolhas genéticas e não está claro por que ser genético importaria aqui (FELDHAUS, 2007, p. 114).

Isso quer dizer que a crítica que Mameli dirige a Habermas envereda por um equívoco de Habermas, qual seja, o de pressupor um mapa impreciso do desenvolvimento psicológico, pois, se é verdade que existem efeitos ambientais irreversíveis, é também verdade que há efeitos genéticos reversíveis (MAMELI, 2007). Como deixa claro Feldhaus, portanto, o núcleo da objeção de Mameli a Habermas

[...] é a afirmação que as pessoas geneticamente manipuladas seriam agentes morais defeituosos ou não plenos participantes seja da sua própria perspectiva seja da dos outros. Para Mameli, o custo de recusar-se a adotar responsabilidade é muito alto, por isso as pessoas não iriam desejar ou escolher não ser responsáveis (FELDHAUS, 2007, p. 115).

O que deve ser dito é que a proposta habermasiana apresenta-se como consistente e sustentável. É em razão disso que tem levantado e suscitado críticas. Outros autores desenvolveram críticas plausíveis às teses de Habermas. O trato dado aos autores acima apresentados deu-se com base na importância do ponto em que tocavam nas ideias de Habermas. ${ }^{9}$

\footnotetext{
${ }^{9}$ Um último ponto não deve ser omitido: a discussão de muitos posicionamentos de Habermas suscitou um debate com pensadores, como Dworkin e Nagel, que provocou uma resposta do frankffurtiano, inclusa no Posfácio do livro O Futuro da Natureza Humana. Ver: HABERMAS, J. Posfácio, p. 103-35 (final de 2001/início de 2002). In: Futuro da Natureza Humana. $2^{\text {a }}$ Ed. São Paulo: Martins Fontes, 2010. De modo simples, Habermas explica alguns pontos e reconsidera outros. Essa questão, contudo, porque se estende para além dos fins desse trabalho, não será abordada aqui.
} 


\section{Considerações Finais}

Como conclusão, cabe dizer que a estratégia argumentativa de Habermas, contra a eugenia liberal e em favor da eugenia negativa, embora sofisticada, depende da comprovação de certos nexos causais entre a intervenção genética e os efeitos apontados à liberdade ética do ser humano que sofreu alteração genética. Além disso, Habermas traça distinções entre a determinação ocasionada pelos pais à liberdade ética dos filhos no caso da educação e da manipulação genética que precisam ser comprovados. No caso da educação, é possível aos filhos uma atitude de revisão em relação às determinações advindas das decisões paternas no que tange aos seus planos racionais de vida. Isso, contudo, não ocorre no caso das determinações resultantes de intervenção genética, haja vista tais intervenções terem o caráter irreversível, conforme visto.

É interessante ter em conta que, mesmo que se aceite a necessidade de comprovação dos nexos causais entre a intervenção genética e os efeitos apontados à liberdade ética do ser humano, Habermas não incorre em determinismo genético, visto que seu argumento centra-se no dano à liberdade ética de um futuro membro da comunidade dos seres dotados de relevância moral. Conforme viu-se, Habermas defende, na linha de Kant, que o ser humano não pode ser instrumentalizável, o que conduz a concepção de que ele deve ser tratado - assim como a humanidade - como um fim em si mesmo.

Além disso, é certo que a biotecnologia, ipso facto, altera a fronteira entre o que é dado pela natureza e o que está à disposição do homem para ser alterado. Sendo essa fronteira imprecisa, é do domínio da ética da espécie a determinação da identidade do homem com relação ao que é dado e ao que é disponível livremente, de tal forma que a identidade da espécie humana afirma-se como uma marca de indisponibilidade do que é dado.

Certo é que não há argumentos morais disponíveis suficientes para impedir a eugenia, pois, conforme assevera Volpato Dutra (VOLPATO DUTRA, 2005, p. 271), o discurso dos direitos humanos não consegue resolver a questão, visto que pressupõe a noção de pessoa, cuja aplicação à vida pré-natal é polêmica e controversa, recaindo, nesse sentido, à concepção de bem, em termos de linguagem rawlsiana. Desse ponto de vista, há implicação numa visão liberal pela qual se exige a neutralidade do Estado, que poderia apenas regular tais os procedimentos, frente a questões de tais tipos, recaindo esta na decisão particular dos cidadãos. 
Todavia, como Habermas considera, a eugenia determina uma mudança no autoentendimento como membros da espécie, tendo em vista alterar o que era considerado natural, isto é, a natureza humana biológica. A intervenção genética quebra a simetria relacional, alterando a imagem e a identidade individuais de tal forma a não ser mais reversível. Por isso mesmo, ela deve ser considerada como uma violação injustificável da autonomia pessoal e do princípio da igualdade, pois muda a imagem dos seres humanos como livres e iguais. Por assim dizer, nos termos de Honnefelder, a heteronomia da natureza deve ser respeitada porque mantém a autonomia e a igualdade mais fortemente do que a intervenção de terceiros no material genético humano - exceto, quando atender aos objetivos da lógica da cura (HONNEFELDER, 2008, p. 76).

Não obstante, Habermas defende que, a partir da racionalidade comunicativa, deve-se encontrar um limite na proteção da liberdade de escolha das pessoas, assim como em relações simétricas ou iguais. Assim, a eugenia no entendimento de Habermas, permite a ingerência do Estado, embora, tenha-se que distinguir, para isso, eugenia liberal de eugenia autoritária. ${ }^{10}$ Isso porque, agindo dessa forma, age-se em nome da proteção da liberdade e da igualdade, como no caso da limitação do exercício da liberdade de propriedade no mercado, ao impedir monopólios, significa uma proteção do próprio mercado através de uma regra contrária ao mercado (VOLPATO DUTRA, 2005, p. 247).

\footnotetext{
${ }^{10}$ Habermas, em breves traços, sob a influência de Agar, distingue eugenia liberal de autoritária: enquanto aquela está sob a égide do livre mercado, segundo preceitos liberais, tais como livre iniciativa e preferências pessoais, esta é controlada e estabelecida pelo Estado. O fito que aqui se pretende é atinente à explicação de que, ao permitir a ingerência do Estado, Habermas não está a dizer que ela deva ser controlada autoritariamente por ele (tendo em vista ter-se em conta o estabelecimento de preceitos protegendo o patrimônio genético), mas, que ela não deve ter a formatação do livre mercado. Cf HABERMAS, 2004, p. 26-7; 67-8.
} 


\section{REFERÊNCIAS BIBLIOGRÁFICAS}

AGAR, Nicholas. Liberal Eugenics: In Defence of Human Enhancement. Oxford: Blackwell Publishing, 2004.

CHITTY, Claide. Eugenics, Race and Intelligence in Education. London: Continuum International Publishing, 2009.

DALL'AGNOL, Darlei. Bioética. Rio de Janeiro: Zahar Ed, 2005.

2005.

O Passado da Natureza Humana? ethic@, Florianópolis, v.4, n. 3, p.321-326, Dez

DEVOLDER, Katrien. Cloning. The Stanford Encyclopedia of Philosophy (Summer 2013 Edition), $\quad$ Edward N. Zalta (ed.), URL http://plato.stanford.edu/archives/sum2013/entries/cloning/, acessado em 12/08/13.

DWORKIN, Ronald. Sovereign Virtue: The Theory and Practice of Equality. Cambridge: Harvard University Press, 2002.

Domínio da Vida. Trad. Jeferson Luiz Camargo. São Paulo: Martins Fontes, 2009.

FELDHAUS, Charles. Habermas, Ética da Espécie e seus Críticos. Princípios, Natal, v. 14, n. 22, jul./dez. 2007, p. 93-122.

. A Eugenia Liberal e o Futuro das Espécies. Filosofia, Ciência e Vida, São Paulo, Ano II, no 21, 2008, p. 56-63.

. O Futuro da Natureza Humana de Jürgen Habermas: Um comentário. ethic@, Florianópolis, v.4, n. 3, p.309-319, Dez 2005.

FELIPE, Sônia T. Equívocos da Crítica Habermasiana à Eugenia Liberal. ethic@, Florianópolis, v.4, n. 3, p.339-359, Dez 2005.

GALTON, Francis. Hereditary Talent and Genius. Apud: GOLDIM, José Roberto. Eugenia. In: http://www.ufrgs.br/bioetica/eugenia.htm, acessado em 05/06/2010.

GUEST, Stephen. Ronald Dworkin. Rio de Janeiro: Elsevier, 2010.

HABERMAS, J. O Futuro da Natureza Humana. A caminho de uma eugenia liberal?. Trad. Karina Jannini. São Paulo: Martins Fontes, 2004.

HONNEFELDER, Ludger. Bioethics and the Normative Concept of Human Selfhood. In: DÜWELL, M.; REHMANN-SUTTER, C.; e MIETH, D. (Orgs.) The Contingent Nature of Life Bioethics and Limits of Human Existence. Dordrecht: Springer, 2008. 
KERSTING, W. Liberdade e Liberalismo. Trad. Luís Marcos Sander. Porto Alegre: EDIPUCRS, 2005.

KEVLES, Daniel. Eugenics. In: POST, Stephen G. (Org.) Encyclopedia of Bioethics. $3^{\mathrm{a}}$ ed. New York: MacMillan, 2003.

MAMELI, Mateo. Reproductive Cloning, Genetic Enginnering and the Autonomy of the Child: the Moral Agent and the open Future. Journal of Medical Ethics, 33, 2007, p. 87-93. Disponível em: http://www.ncbi.nlm.nih.gov/pmc/articles/PMC2598241/, acessado em 10/08/13.

PEGORARO, Olinto A. Ética dos Maiores Mestres da História. Petrópolis, RJ: Vozes, 2006.

PLATÃo. A República. Trad. Maria Helena da Rocha Pereira. $9^{a}$ ed. Fundação Lisboa: Calouste Gulbenkian, 2001.

SANDEL, Michel. J., The Case Against Perfection. Ethics in the Age of Genetic Engineering. Cambridge, MA: The Belknap Press of Harvard University Press, 2007.

VOLPATO DUTRA, Delamar J. Razão e Consenso em Habermas. $2^{\mathrm{a}}$ ed. Florianópolis: Editora da UFSC, 2005.

. Seria a Eugenia Liberal Míope? ethic@, Florianópolis, v.4, n.3, p. 327-337, Dez 2005. 